\title{
Integrating Technology Into The Freshman Year Experience Classes At Purdue University Calumet
}

Deborah L. Thinnes, (Email: thinnes@calumet.purdue.edu), Purdue University, Calumet

\begin{abstract}
This paper examines a one-credit hour Freshman Year Experience (FYE) course that was implemented within the School of Management at a regional campus of a Big Ten university. Additionally, the paper also discusses the integration of the University's course management system in order to properly prepare management students to be successful in their academic degreed programs.
\end{abstract}

\section{INTRODUCTION}

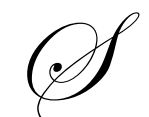

ince Fall 2003, WebCT Vista, a course management system, was used for all distance learning courses and as a supplement to many traditional, on-campus courses. WebCT Vista Version 3.0 is an enterprise course management system with a robust set of tools such as announcements, email, discussions, assignments, and assessments.

At the time, there were two course management systems in use at Purdue University Calumet: Blackboard and WebCT Vista. Since the decision had been made to discontinue the usage of the Blackboard system as of Summer 2005, the WebCT Vista was integrated into the Freshman Year Experience classes. Research studies suggest that "technology is an instructional tool, but it has also become an integral and growing part of student's lives. For that reason, it is important the technology is integrated into the learning environment not as an add-on, but as a part of a seamless system of preparing students for the information age.” (Kealey, 2000)

\section{METHODOLOGY IN IMPLEMENTING TECHNOLOGY}

Other higher education institutions have faced similar challenges when integrating technology into the classroom, For example, the success of implementing WebCT Vista at Oakland University, Rochester, MI, has been attributed to leadership, faculty adoption and training, network stability, and instructional technology unit management (Cheal, 2005). The infrastructure with the Purdue University Calumet has been established to support WebCT Vista. An advisory group referred to as CMIST (Course Management Implementation and Support Team) was formed and its membership consisted of representatives from each School within the University. I was appointed as the School of Management's representative. A WebCT Vista administrator was selected at Purdue Calumet to coordinate the technical and support efforts between the other four Purdue campuses (West Lafayette, Calumet, Fort Wayne and North Central). The technical support component of this project was primarily housed at the main campus in West Lafayette, Indiana. Through the CMIST team, support was provided from the upper university administration (Chancellor, Vice Chancellor for Academic Affairs and Vice Chancellor for Computing and User Services). Although the first year of installation and implementation of WebCT created many stability issues for the faculty and students, the product was relatively stable by the time it was introduced into the Freshman Year Experience courses.

In Spring 2004, the Freshman Year Experience (FYE) courses within the School of Management began with Ms. Eva Brickman as the Director of the Freshman Year Experience. She had extensive experience with the university in the areas of advising, education and counseling. At this time, no technology was used in this course. 
When I was asked to teach four of the ten FYE classes in the Fall 2004 semester, I suggested that we integrate technology into this course. At this point, staff training was important to ensure the success of integrating the technology into this course. Instilling comfort and confidence in using a computer system is essential to the success of any integration of technology, especially with teachers at the University of Pittsburgh in their PT3 Project which prepared teachers to use technology (Campbell \& Ozgul, 2002). Change management requires that we recognize fears and devise plans that build staff confidence and motivation and provide adequate support and training opportunities. (McNaught, 2002). Such fears create barriers and can be broken down into four main categories: concerns of the individual incompatibility, concerns of the unknown, concerns of organization support, and concerns of organization incompatibility (Lee, 2001). In order to ensure success of this technology, these fears and concerns would have to be carefully managed, both from the instructor and student perspectives.

During the first days of class, both instructors attended all Freshman Year Experience classes. My primary role was to teach the technology section of the class. To be successful, for teachers to teach expertly we need to be "be the technology" by modeling its use in the classroom (Mills and Tincher, 2002). Therefore, we had to fully prepare ourselves and allow the technology to have an impact on how and what we taught; a significant change in methodology and thus creating a new paradigm.

Within the first few weeks of classes, student's at all academic levels, from freshman to senior, were struggling to quickly learn this new course management system, WebCT Vista. In an effort to alleviate this concern, two-hour WebCT help sessions were offered to those enrolled in our online management courses. In addition, open lab times were scheduled during the freshmen's second week of classes. My strength I brought to this project was the technical expertise that I gained using several versions of the WebCT Vista product. Since many classes at the University were planning to use WebCT Vista, I felt that our freshman students would benefit from being exposed to this technology at an early stage in their academic careers.

Fox (1983) emphasizes four theories of teaching: transfer theory, shaping theory, traveling theory and growing theory. These theories are further explained in the context of fitting modern technology into established teaching (Siemer-Matravers, 2000). In the transfer theory, learning is seen as a process in which knowledge represents a commodity that needs to be transferred from the teacher to the learner. An example of this can be seen in document dissemination to the freshman students. The shaping theory advocates the learner as having to be shaped into a particular specification, demonstrate a particular task and put into practice by the student. This educational approach was modeled in the Freshman Experience classes at Purdue University Calumet through the email exercises. In the growing theory, the teacher can be viewed as a gardener within the student's mind; emphasizing the development of the learner as a human. We viewed the integration of WebCT Vista technology as a way to improve retention and promote student success within the School of Management, in with the context of the University's strategic plans.

Consistency between classes is important and shells or templates in WebCT Vista are excellent tools. At the College of St. Scholastica in Duluth, MN, a "shell" was structured for a number of courses so that instructors could customize it to their needs and the various learning styles of their students (Bongey, Cizadlo and Kalnbach, 2005). At Purdue Calumet, because there were ten sections of the FYE courses, a "template" was also designed with some basic information such as a course syllabus, course outline, and exam study guides. This template served as a model for the ten sections of the course, providing consistent information among the classes. Demonstrations were given to the students in the first class about this new product and its features. The course instructors reinforced to the students that this information would be useful in this class as well as throughout their academic career at Purdue University Calumet.

One of the requirements in implementing this technology into the FYE courses was that WebCT Vista was easy to use (in computer terms, user-friendly). Results of a preliminary study at West Virginia Northern Community college indicate the orientation and structured interactions play an integral role in student retention (Sharma, 2005). To achieve this goal, we were careful to limit the tools that were made available to the students in this course. Research studies reveal that successful blended classrooms combine the weekly face-to-face instruction with the easy- 
of-access to online materials and support. (Orsini-Jones \& Courtney, 2005). The FYE courses were using WebCT Vista in this blended classroom environment and were never intended to become fully online classes.

We encouraged the use of several of Chickering and Gamson's (1987) "Seven Principles for Good Practice in Undergraduate Education" as they applied to technology. Specifically, dealing with the objective of good teaching practice encourages contact between students and faculty; we insisted that any email communication be accomplished through WebCT Vista. At Purdue University Calumet, we have another intranet mail product, Groupwise, but we recommended that the students use the WebCT Vista email exclusively. Email is internal to WebCT Vista, so we did not have to know who the students' internet service provider was or worry about updating their email addresses if their service providers changed. Research indicates that practicing is important to learning. One of the first assignments the students received was the assignment to send his/her instructor an email message in WebCT Vista.

An important component of course delivery is deciding how the students learn the "rules of the course". (Parker and Hankins, 2002) An online tutorial in Vista was introduced and demonstrated in the first class. At the end of the online tutorial, the students could take an online quiz to reveal their aptitude on the material that was covered. This was an excellent approach to have the students use the online assessment tool in Vista. In addition to handing out the course syllabus and schedule on the first day of class, the website contained also these documents. (Posting documents to the website eliminated the necessity of the instructors carrying extra copies of materials to class). Students could also retake the quiz multiple times. Research suggests that the retention rate is $75 \%$ when students are required to practice what they have learned (Formosa, 2001). Feedback is automatic with online quizzes taken through WebCT Vista, modeling another one of the seven principles, which states that good teaching practice gives prompt feedback. (Chickering and Gamson, 1987).

Course materials (in the form of Microsoft Word documents) were placed on the website that were not also distributed in class. This approach forced the students to access the course website to obtain the materials. Announcements were routinely posted regarding the details of the course. For example, announcements reminded the students of the upcoming deadlines, room changes, and other changes made in the course. The assumption was made that most students were familiar with some form of text messaging or email functions. However, the demonstrations of email given in class assumed no such knowledge on the part of the students. The instructors would remind students if they used another email. We also guaranteed instructor feedback response within 24 hours of the students' email, excluding weekends.

Another WebCT Vista tool that was introduced was the Gradebook. At any time, the students could access their grades and check on their progress in the course. Additionally, students were responsible to check the accuracy of posting the grades and letting their instructors know of any discrepancies they found.

\section{CONCLUSION}

In summary, this paper has examined the implementing technology into the Freshman Year Experience (FYE) courses in the School of Management at Purdue University Calumet. The approach consisted of removing barriers to integrating technology into the classes, both for the students and for the instructors. The success of the project was due to support from top executives at the University, support between departments and other Purdue campuses, and continuous training for all instructional staff. Students gained confidence and experience with the WebCT Vista system through viewing demonstrations, encouraging words from their instructors and practicing the various WebCT Vista tools.

In retrospect, methods of assessment should be developed to measure success or failure of integrating technology into Freshman Year Experience (FYE) classes at Purdue University Calumet. These assessments should include input from both the student and instructional staff's perspective. Based on these assessment results, improvements can be made to future classes as the course is continuously revised and changed to meet the needs of our School of Management freshmen students at Purdue University Calumet. 


\section{REFERENCES}

1. Bongey, Sarah E. Bryans, Cizadlo, Gerald, and Kalnbach, Lynn (2005) Using a Course Management System (CMS) to meet the Challenges of Large Lecture Classes. Conference paper presented at the Impact 2005, $7^{\text {th }}$ Annual WebCT User Conference, July 2005.

2. $\quad$ Campbell, Shirley and Ozgul, Songul (2002). First Year of Technology Mentoring for Teachers and Faculty: Lessons Learned. ED-Media 2002 World Conference on Educational Multimedia, Hypermedia \& Telecommunications, 2002.

3. Cheal, Cathy (2005). The Success of WebCT: Integration through Policy Development. Conference paper presented at the Impact 2005, $7^{\text {th }}$ Annual WebCT User Conference, July 2005.

4. $\quad$ Chickering, Arthur W. and Gamson, Z. (1987), Seven Principles of good practice in Undergraduate Education. AAHE Bulletin, 39, pp. 3-7.

5. Formosa, James (2001), Using Technology to Improve Student Outcomes in Traditional Classroom Courses. Paper presented at the Fifth Annual Distance Learning Conference, Nashville, Tennessee, February 22, 2001.

6. Fox, D., Personal Theories of Teaching (1983) in Siemers-Matravers, Julika. Fitting Modern Technology into Established Teaching Practices. Conference paper presented at the European Conference on Lifelong Learning, 2000.

7. Kealey, Robert J., Ed (2000) Examples of the Integration of Technology in the Classroom. 2000.

8. Lee, HeeKap (2001). Teachers’ Perceptions of Technology: Four Categories of Concerns, Annual Proceedings of Selected Research and Development [and] Practice Papers, Presented at the National Convention of the Association for Educational Communications and Technology, 2001.

9. McNaught, Carmel (2002) Implementing Technology in Higher Education: The Management of Multiple Dimensions. ED-Media 2002 World Conference on Educational Multimedia, Hypermedia \& Telecommunications, 2002.

10. Mills, Steven C. and Tincher, Robert C. (2002) Be the Technology: Redefining Technology Integration in Classrooms. NECC 2002: National Educational Computing Conference Proceedings, 2002.

11. Orsini-Jones, Marina and Courtney (2005) Increasing Learning Opportunities for Students through Blended Learning. Conference paper presented at the Impact 2005, $7^{\text {th }}$ Annual WebCT User Conference, July 2005.

12. Parker, Brenda and Hankins, Judith (2002) The Joys and Sorrows of Teaching Computer Literacy Online. Conference paper presented at the National Education Computing Conference, 2002.

13. Sharma, Purnima V. (2005) Facilitation and Student Retention in Outline Courses. Conference paper presented at the Impact 2005, $7^{\text {th }}$ Annual WebCT User Conference, July 2005.

14. Fox, D., Personal Theories of Teaching (1983) in Siemers-Matravers, Julika. Fitting Modern Technology into Established Teaching Practices. Conference paper presented at the European Conference on Lifelong Learning, 2000. 